\title{
Os Benefícios da Educação Assistida por Cães em Intervenções Numa Enfermaria Psiquiátrica Pediátrica: Relato de Experiência
}

\author{
Petenucci, Andrea Lorenzon; Lopes, Laura Leães \\ TAC — educacaoassistida@gmail.com
}

Introdução o trabalho trata de um projeto pedagógico implantado no início de 2011 que prioriza a humanização hospitalar através de atividades educativas assistidas por cães terapeutas. o projeto atende crianças e jovens internados na enfermaria psiquiátrica pediátrica de um hospital de alta complexidade. Objetivo o objetivo visa relatar os benefícios do contato com o cão terapeuta como motivador para a adesão as atividades pedagógicas que promovem a manutenção do processo de ensino-aprendizagem durante a internação hospitalar. Método o relato de experiência baseia-se nas atividades pedagógicas realizadas semanalmente em função do público atendido pela enfermaria pediátrica psiquiátrica pautadas em três eixos: leitura, jogos e contato com os cães terapeutas. o relato também descreve como é desenvolvido o material de trabalho utilizado nas dinâmicas com os cães terapeutas. Resultado: o projeto alcançou adesão em relação às atividades de pacientes com quadros, tais como TOC, isolamento, mutismo, TDAH, entre outros, bem como a participação em produções textuais e artísticas. As atividades desenvolvidas contribuíram para despertar a socialização dos pacientes internados na enfermaria pediátrica e a interação no grupo. Conclusão Este projeto permite concluirmos que o cão promove a adesão às atividades e a interação em grupo e devido a isso é importante a divulgação da atuação de profissionais na Educação Assistida por Cães. É necessário conscientizar os gestores hospitalares sobre a importância da pedagogia hospitalar e, principalmente, da Educação Assistida por Cães para que os hospitais abram suas portas a essa prática dando espaço para pesquisas científicas sobre este tema.

Petenucci, Andrea Lorenzon; Lopes, Laura Leães. Os Benefícios da Educação Assistida por Cães em Intervenções Numa Enfermaria Psiquiátrica Pediátrica: Relato de Experiência. In: Anais do Congresso Internacional de Humanidades \& Humanização em Saúde [= Blucher Medical Proceedings, num.2, vol.1]. São Paulo: Editora Blucher, 2014. ISSN 2357-7282

DOI 10.5151/medpro-cihhs-10538 